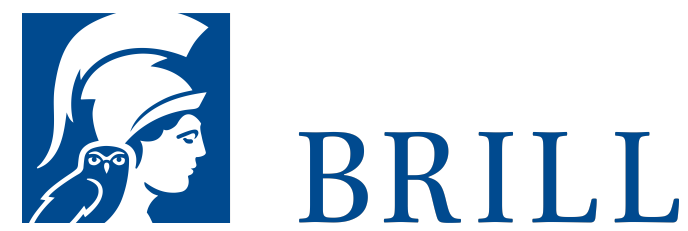

\title{
Marshall Hall (1790-1857)
}

Science and Medicine in Early Victorian Society

Author: Diana E. Manuel

Marshall Hall was trained as a physician in the early nineteenth century, scientifically oriented, University of Edinburgh Medical School. The son of a Methodist cotton manufacturer and bleacher at Nottingham, Hall believed that in science lay the future for progress in medicine. Following early work on diagnosis, on women's disorders and on blood-letting, Hall came to specialise in the nervous system and in particular on the concept of reflex action. For Hall, who proposed a mechanistic explanation of reflex action, Galenic animal spirits and souls in decapitated creatures were out.

A superb experimentalist, Hall strove to establish experimental medicine (physiology) as the basis of the medical curriculum instead of anatomy, the long standing domain of the surgeons. They were among the strongest critics of Hall's vivisection procedures, despite his efforts to establish a Code of Practice. Hall was involved in several controversies within and without the Royal Society where he was victimised by its Physiological Committee. He addressed a range of social and public health issues including the abolition of slavery, and devised a new method of resuscitation and a more sensitive physiological test for strychnine detection. He also proposed plans for improving and linking sewage disposal and the transport system of the metropolis.

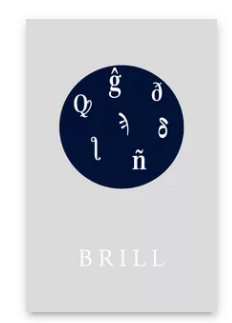

Pages: xiii, 378

pp.

Language:

English

Subjects:

History of

Medicine,

History

Publisher: Brill

Series:

Clio Medica

Online, Volume:

37

Clio Medica,

Volume: 37

E-Book (PDF)

Released online:

$29 \mathrm{Jan} 2020$

ISBN: 978-90-

04-41846-2

List price

USSD \$207.00

Hardback

Publication date:

o1 Jan 1996

ISBN: 978-90-

5183-921-O

Paperback

Publication date:

o1 Jan 1996

ISBN: 978-90-

5183-905-O 
Dr Diana E. Manuel, a former student of Sir Peter Medawar, spent 24 years as an academic at the University of Durham, whence she succeeded in gaining early retirement in 1993. She became an Honorary Research Fellow in the History of Medicine at the Wellcome Institute for the History of Medicine, which has earlier awarded her a Research Fellowship to work on the present book.

For more information see brill.com

Order information: Order online at brill.com +44330 333 o049 | customerservices@brill.com Submission information: brill.com/authors

Titles published by Brill | Fink, Brill | mentis or Brill | Schöningh: +49(o)71 5413279216 | brill@brocom.de 